\title{
The relationship between competence and career path planning: An applied study
}

\author{
Layla saad alhashem*
}

Lecturer at Management Department - College of Business Administration King Saud University 


\begin{abstract}
The aim of this study is to identify the competence of employees in fast food restaurants to plan their career path. The researcher utilized descriptive analytical method. The research sample is composed of 200 employees. The researcher use a tool to collect research data.

The results of the research found out different consequences, the most fundamentally are :

1. The knowledge and skills related to the field of work came to a large extent. The general average of the level of this axis (2.59), the standard deviation (0.63) and the general level trend (large).

2. The requirement of the employees capability to utilize the resources needed for the performance of his work according to the research community where the general level average (2.63), the standard deviation (0.57) and the general level trend (large).

3. The necessity for a correlation between colleagues in the work according to the research community, where the general level average (67.2), standard deviation (0.56) and the general level trend (large).

4. The significance of improving a plan for the jobs that the employees hope to occupy in the future, where the average levels of this axis (2.65), the standard deviation (0.56) and the general trend level (large).

The study recommended the following: To define the employees with the tasks and actions that must be performed. As well as encouraging employees to come up with new ideas and work to support them.
\end{abstract}




\section{Introduction:}

No doubt that the human resources have main features that make them unique from other resources. This has led for being considered as a human capital which contributes to the shaping of a competitive advantage of the organization. This organization is concerned with the employees' professional development to enable them to deal with many variables, such as economic, political, and technological variables. Since the development of the efficiency of a job is regarded as a point of focus for the human resources itself. Competence is defined as a set of knowledge, skills and abilities that individuals have; in order to achieve these tasks or jobs that are required of them at the required level (Jihad, 2011). Mondy and R. Wayne (2010) indicate that the entrance to competence represents the third wave of management and comes after the first wave (bureaucracy) and the second wave (management by objectives).

In addition to that, the concept of competence is one of the concepts that appeared in the seventies of the last century. However, the writings started in the 1980s, and the conception of human resources management based on competence appeared to reflect the utilize of competence in the achievement of human resources functions from polarization, employment, training, development and career planning.

In spite of the fact that there are numerous definitions of competence from various standpoints, there is almost an agreement to contain the skills, knowledge and capacities needed to perform the work. This makes individuals are concerned with developing themselves in order to get diverse jobs in proportion to the future; especially after the development of the concept of career planning during the industrial revolution and the expansion of the production system. Career path delineation (according to the traditional view) was regarded to be the only organization responsible for delineation the career path and within the boundaries of the organization only. Moreover, it becomes in an upward direction as individuals permanently climb up as long as they perform their work effectively and efficiently. However, in the beginning of the 20th century, there was an alteration in career planning concept to be defined as Boundaryless Career; it is characterized being flexible. Thus, the appearance of a newfangled pattern of career path is multi-directional and affords the individual independence to climb onto the same path or another new path. The organization is no longer merely responsible for career planning, but the concept of career planning has become a shared responsibility of the individual, the organization and the instant managers. The individual is basically responsible for designing the career path. In view of the important role played by career planning, the organization may seek the assistance of outside 
consultants to assist staff in planning their careers. (Jung and Takeuchi, 2016) point out that career planning does not occur once in life, but is a persistent activity that drives the individual to improve and progress, as well as to manage his or her career.

The efficient merit contributes outstandingly to the accomplishment of the employees' plan for their careers, which supports to promote the performance of the employees and to originate a second class of staff. Therefore, it helps the organization to depend upon interior resources as a strategy to treat with conditions of insufficiency in those cadres. Ashoch (2015) observe that the causes for the increased attention to the concept of career paths at the present time. As well, how the individual is suffering from lack of access to such opportunities for promotion and development career path; this is reflected in the performance, turnover rate, and then affected on the results of the work of the organization negatively or positively.

\section{Research problem:}

In the light of the results of the review of previous studies, there is a lack of studies on career planning as well as functional merit, which makes the researcher can contrive the problem of research in the following scientific question:

-What is the effect of the efficiency of employees in fast food restaurants to plan their careers?

This question is divided into a number of scientific questions:

1. What is the significance of career planning for employees in fast food restaurants?

2. What are the implications of stimulating the function of merit in fast food restaurants?

3. What are the ultimate significant dimensions of merit in career planning in fast food restaurants?

\section{Study hypotheses:}

1. There is a statistically significant relationship between the individual's knowledge of work skills and his ability to use the resources required for his work

2. There is a statistically significant relationship between colleagues' relationships in work and their ability to use the resources required for their work

3. There is a statistically significant relationship between the individual's knowledge of work skills and the planning of his / her functions in the future 4. There is a statistically significant relationship between the worker's ability to use the resources needed for his work and planning his future jobs 


\section{Research goals:}

In determining research problem, research goals can be defined as follows:

1. Defining the dimension of the effect of merit on career planning and determine the strength of this effect.

2. Study the factors that help to plan the career path of workers in fast food restaurants and identify the most important of these factors.

3. Determine the most important dimensions of merit affect the planning of the career path of workers in fast food restaurants.

4. Identify the most important means and standards that enable human resources management to strengthen the career path of employees in the hospitality industry.

\section{Research importance:}

The importance of the research is as follows:

\section{.1. Theoretical Importance (Research Subject)}

The theoretical importance of this research is restricted in the previous studies that dealt with the relationship among merit and career planning, in spite of the importance of these two variables as mentioned in the previous studies. Furthermore, there was no studies that examined this relationship scientifically. Relationship theory studies which displays the importance of this research. Furthermore, it is imperative to pay attention for improving the merit of the most important resource owned by the organization and seek to invest in it; by maximizing the return from it. It is the human resource, which demonstrates the accomplishment of the current and future strategic competitive advantage of the organization; regardless of the importance of this topic.

2. Practical importance (scope of application)

The practical importance of picking out a fast food restaurant sector as the area of application is due to the following reasons:

- Fast food restaurants (one segment of the tourism sector) are considered as sectors that have not been sufficiently addressed in previous studies, in spite of their importance.

- The restaurant sector is one of the components of tourism, which in turn is a fundamental pillar of the Saudi national economy and a contribution to the GDP

- Fast food restaurants are the most important sectors that absorb a lot of human resources at different levels of education (Mohammed I. Eraqi et al, 2011).

Search limits:

Spatial boundaries: The study is limited to McDonald's fast food restaurants in Saudi Arabia.

Time Limits: The researcher began collecting data for the purposes of this study in 2019. 
Human Boundaries: Includes employees and senior management of McDonald's, which operates fast food restaurants.

\section{Previous studies:}

\section{Previous studies that dealt with merit}

1. (Badawi\& Farah 2018). This study aimed to investigate the significant statistical correlation and impact of Information Technology on Development of Human Resources Digital Competence in Saudi Construction and Contracting Companies at ABSAR in Saudi Arabia Kingdom. The study followed the analytical descriptive method supplemented by the statistical analytical techniques, besides; designed a questionnaire covered the random sample of 200 engineers and clerks in the company. The most important findings of the study were: there is a significant positive strong statistical correlation between Information Technology and Development of Human Resources Digital Competence. Also, there is a significant impact of Information Technology on Development of Human Resources Digital Competence.

2. Sengupta (2013) study, conducted on HR staff in Indian spinning and weaving institutions, purposed to use the merit model in performance management to fulfill competitive advantage. The results pointed out that the merit approach is regarded as a key element for the expansion of performance. Also, the results added that there is a vigorous relationship between the merit model and performance management. Since the performance management is a strategic function of human resources management, it helps the organization to achieve competitive advantage.

3.(Alice.H.y Hon, 2012) study, for hotel workers in Hong Kong, purposed to determine the effect of the merit approach on indemnification and benefits. Accordingly, it has been found that merit conspicuously effects the determination of indemnification and benefits for hotel workers.

Previous studies that dealt with the subject of career path.

1.( Awarib, Abdelgadir 2015) Study of the relationship between the availability of these requirements and their role in motivating employees, As the aim of this study is to answer the question whether there is a differential impact of dimensions of career planning to motivate staff, In order to address the problems we have distributed a questionnaire prepared for this purpose to view of study and of 41, and all have recovered, The study found the most important set of results, there is a statistical relationship between the effect of dimensions of career planning in motivating employees, and promotion is the most influential component of other components. 
2. Skilton study (2008) aimed at indicating the impact of some elements (type of project, organizational structure) on career planning, and pointed out that these elements had a considerable impact on career planning.

3. Tarawneh study (2010), at Ministry of Finance in Jordan, aimed at studying the effect of human resource management functions (training and development, transportation, performance evaluation and performance bonuses) on career planning. The outcomes affirmed that both the training and development function have a powerful effect on planning, the training and development function. The ability and expertise of staff are developed. The outcomes also denote that performance assessment influence on career planning as one of the expansion and promotion of the organization.

\section{Previous studies that dealt with the subject of career path.}

1. Skilton (2008) aimed at identifying the effect of some factors (type of project, organizational structure) on career planning, and found that these factors had a significant impact on career planning.

2. The Tarawneh 2010 study aimed at the Ministry of Finance in Jordan to study the impact of human resources management functions (training and development, transportation, performance evaluation and performance bonuses) on career planning. The results confirmed that both the training and development function have a strong effect on planning Career path. Through the training and development function, the ability and skills of staff are sophisticated. The outcomes also point out that the performance assessment influences on career planning as one of the improvement and advancement of the organization.

\section{Previous studies that focused on the impact of merit on career planning:}

1. Cappellen and Jenssens study(2008) aimed at testing the effect of merit of Swedish real estate managers on job planning and development. The results pointed out that managers were concerned with knowledge to promote their careers.

2. (Pinnington, 2011) study, conducted on directors of pharma pharmaceutical company in Belgium, aimed to identify the influence of merit development on the expansion of the career path. Thus, the results manifested that the development of merit substantially impacts on the development of the career path of the employees of this company.

3. (Bocciardi et al., 2017) study aimed at handling the effect of promoting individual merit of employees in the industrial sector in Britain on the development and planning of career paths. The results showed that merit has a considerable impact on planning and career development.

Comments on previous studies: 
After exhibiting the previous studies and research, it can be noticed the following points:

- The shortage of studies that effect on the merit of career planning.

- The current study is convenient for the previous studies in the methodology of the research as most studies adopted the descriptive approach.

- The results of previous studies pointed out that merit can contribute to career development.

- The present study has benefited from the results of previous studies in selecting the methodology of the study, designing its tools, and confirming the idea of merit, as it can contribute to the development of the career path.

- Benefit from previous studies in the preparation of the theoretical framework of the current study, besides knowing the statistical methods and treatments used in proportion of the current study in terms of emphasizing on the equivalence of groups of study before starting the processing application; to evolve the results and to find answers for the study questions.

\section{Research terms:}

competence:

Merit is a set of personal characteristics that can drive to prominent performance and competence (Mamaqi et al., 2011).

The researcher determines the practical merit as: the acquisition of knowledge, abilities and skills that regulate the experience of the workers that contribute in obtaining superiority in performance.

Career path planning:

Career Planning is the official approach used by the organization to enable individuals to acquire the skills and expertise; required to carry out their current and future career. Job development contributes to maintain a motivated and committed workforce in order to achieve the goals of both the organization and individuals (Mondy.et al, 2005, p. 367).

The researcher defines the career path as a long-term vision that displays the road map of the individual through which his skills and ambitions are developed for self-realization.

\section{Theoretical framework:}

First: competence

Definition of Merit: According to many definitions that dealt with the concept of merit, it has been pointed out that merit is:

- Skills, knowledge and behaviors associated with each other in order to achieve a competitive advantage (Urtasun, Nunez, 2012)

- A personal attribute that makes an individual able to perform tasks (Lester, 2014). 
- The essential personal characteristic through which the individual performs eminent performance as well as the technical skills associated with the field of work and the skills related to the behavior of individuals and how to deal with others (Yu. Chi wu et, el.2015)

- Through the information, knowledge and relationships at work, their professional development is advanced leading to the progress of the organization (Fleisher et al., 2014)

- The capacities, skills and knowledge which are required to perform routine functional activities (Canning and, Szmigin, 2016).

- A set of knowledge, skills and personal qualities that affect one job in order to achieve a competitive advantage (Medina, 2015).

- A set of relevant knowledge, attitudes, skills and other personal qualities that affect a large part of an elementary job (Dada, 2016)

- Ability to apply knowledge and skill to obtain desired results (Bravenboer and Lester, 2016)

Types / Classification of merit:

There are many types of merit or areas in which the human element can excel, which directly contributes to raising the level of performance and achieving merit in this performance. However, many scholars differed in determining the types of merit. The different views of the merit rating will be reviewed as follows:

Rowold \& Kauffeld (2008) has identified three types of merit, which have become more widespread and accepted in vocational training:

A - Professional merit:

Is related to the professional knowledge and skills that are related to the field of specialization or work of the individual, whether related to the organizational aspects of the job or the procedures of the steps of the performance of the job functions of the performance of this function, the individual must have experience in the performance of his work.

$\mathrm{B}$ - Merit in the ways of performing work:

Describes the ability to make good use of the means and resources necessary to perform the work ... The ability to classify the information available to the individual appropriately and to use it to solve work-related problems is an example of this kind of merit.

C - Social merit:

Is about the ability of the individual as a member of a team to communicate and collaborate with his or her team members in an organized and effective manner, an example of this kind of merit: teamwork, conflict management, communication with team members, and ability to deal with customers. 
In another context, merit (Furåker \& Nilsson, 2010) has been classified into functional, social, strategic, personal and artistic merit, and can be illustrated as follows:

\section{Functional merit:}

The ability to solve the problems of work.

Social merit:

The ability to build social relationships and the ability to communicate with others.

Strategic merit:

The ability to identify priorities and the ability to plan long and short term.

Personal merit:

The ability to sense responsibility and the ability to analyze and logical reasoning and decision-making ability.

Technical merit:

The ability to deal with the techniques and technical techniques in the region. Meyer et al., 2015, classified merit differently from the previous study, divided into four types:

-Professionalism: It means that the employee has the professional competence, skills and knowledge in order to practice his work, so that he is able to achieve the objectives of the organization.

-Experience: includes the knowledge and skill that the human resource learns to work in the future and acquire new skills.

-Social merit: The knowledge, skill and experience acquired by the human resource from social interactions.

Self-worth: Ability to self-assessment

3. Elements of merit:

The individual must have the essential elements of performance excellence and include four key elements known as "KSAP" (Mr. 2012):

- Knowledge is destined by information, facts, rules, principles, and theories required for successful job performance.

- Skills is ability to perform the physical or mental function of the individual to achieve the desired results.

- Abilities are the capability or efficiency to perform the job successfully and achieve many desired results such as analysis, problem solving and decisionmaking.

- Personal characteristics is a set of qualities that affect the performance of work effectively and efficiently such as values, attitudes and behavior.

4. Importance of merit:

The importance of merit lies in its strategic role it plays in any organization, which helps to achieve excellence in employee performance. It gives the 
organization a competitive advantage that makes it compete with other organizations (Eden and Ackermann, 2015).

A - The importance of merit at the level of the individual:

1- Urge employees to excel in performance.

.2 - Help the individual achieve organizational goals of the organization

.3 - Help the individual to develop a plan to develop his skills and abilities

.4 - Help the individual to identify his training needs

B - The importance of merit at the level of the organization:

1. Help the organization count on competitive advantage.

2. Merit is a significant input in the formulation of the strategy that will be adopted by the organization whether it is for profit or not.

3. The merit approach helps to improve a merit-based promotion system.

4. Competent human resources management helps to set standards and foundations for HR functions from HR planning, selection, recruitment and compensation.

5. A merit approach helps reduce organized cost.

6. . Help building good reputation among competitors.

7. Help the organization discover outstanding talents.

8. Help the organization to provide good service and value to customers.

9 .Help the Organization in the process of developing its products

Merit Model:

The organization can develop a model for employee merit (Sengupta et., 2013) for prominent performance. The merit model includes three steps and can be explained as follows:

A) Determining the required levels:

The characteristic of merit, required for employees, has been determined by different factors (fulfilling outstanding performance, fulfilling organizational objectives, to fit into the future strategy of the organization). When determining the required frameworks, the current merit should be determined and future merit forecasted.

B) Validity evaluation:

The merit of each individual in the organization has been estimated by utilizing a performance appraisal card to identify the strengths and weaknesses, and then compare them to the competencies in the organization; by the standards of the competing markets, through the following steps:

- Determine the current merit possessed by the individual.

- Determine current competence requirements to meet current job demands.

- Determine the gap among the current merit of the person and the demands of the organization of the current merit. 
- Determine future competence requirements to meet the future needs of the organization

- Define the gap for future merit that is the difference between future merit requirements and existing merit.

- Development of reference merit indicators in the competition market.

- Define the gap of reference merit through the difference between reference merit and current merit.

- Determine the potential merit that is within the organization and has not yet been used.

C ) Coordination between the strategy of the Organization and other functions: The focus of this phase is on the full coordination between the strategy of the organization and the functions of human resources management, in order to gain a competitive advantage by attracting the best elements of the organization, and also through this model to identify the training needs of individuals within the organization by identifying the gap between the current merit and The requirements for merit in the future, leading to the creation of a second row of cadres within the organization, is also a method of determining performance and can also be used to motivate employees and determine compensation based on merit.

Second: Career path planning.

1. Definition of career path planning

It is considered as a continuous exploration process. The individual improves through his self-concept of his professional identity, which obviously determines his nature, abilities, motives, needs, trends and values. As the individual improves in his career path, some of the constants connected with his functional identity become established. These axes rotate around the career path of the individual, (Dessler, 2008).

A persistent process through which the employee sets nominated goals and defines the convenient method to achieve them (Mondy et al., 2005)

2. Types of career paths

Baruch (2004; Smith-Ruig 2008 \& Balochia 2010) detects that several patterns of career paths can be explicated as follows:

A. The traditional path:

It is regarded as the "bureaucratic path", which is the cephalic shift from low to higher positions through advancement. This is a narrow and limited path and is promoted in one direction according to the career ladder. So that, it requires the skills of the employees to obtain their career promotion.

B - The multi-directional career path:

At the end of the twentieth century, after the concept and nature of the job were changed, the concept of a multi-directional career materialized, providing a 
diversity of options for the worker, ie the tendency at the same level of career or changing direction in another career path (James J. et al, 2000). This pattern of path is interested in preparing the worker for success and not necessarily within the traditional career path. In other words, the workers have more than one procedure of expansion in other routes within the organization. The multidirectional path is also a method of maintaining and motivating employees.

One of the features of this track is the elasticity in addition to the selfrealization of the employees. Also, it helps to accomplish the future ambition of the employees. Furthermore, it helps to transform the course of his career according to his penchant, inclination and ability.

C) Career path based on achievements:

It relies on the size of achievements and successes, achieved by the person in his work regardless of the length of time spent in the job. As well, the end of the track is not connected with the retirement year. Thus, the problem here is that the employee can reach the end of the path in the job quickly and staying for a long time causing boredom.

\section{Career Planning Goals:}

Career planning achieves several objectives at both the employee and organization level, as follows:

A. Objectives of career planning at the organizational level

-- Building a vision for the future career path available in the organization, thus reducing the turnover rate of employment.

- Formulating and striving for the organization's human resources strategy.

- Managing the career path that makes the organization responsible for providing the required training programs and developing the personnel.

-- Assisting the organization in succession planning, ie filling vacancies and also predicting employment in quantity and quantity.

- There are no limits to career peace. In the past, there was a functional path that allowed only vertical movement, but now there is a multi-directional career path to overcome the difficulty of moving in the traditional path.

- Improving the working environment of the organization (Shumba, A. \& Naong, M. 2012)

B. Objectives of career planning at the individual level

- Help the individual to compose an obvious picture of the functions that can be occupied in the future

- Capability to have the chance to improve or progress at work

- Realizing job satisfaction

- Help the individual to attain the necessary skills in solving the problems that face him at work 
- Help the individual to promote themselves in order to face their own economic conditions

- Help the individual to enhance and direct his professional orientation and skills (Shumba, A. \& Naong, M. 2012).

4. Responsibility for career planning:

The responsibility of career planning rests with the three parties (staff managers - organization) as follows (Krishnan and Maheshwari, 2011; Tzabbar et al., 2003)(

A. Responsibility of the individual

The literature has finally assured the significance of the function of the individual in designing his career path due to the appearance of new jobs and also an alteration in the organizational structures, so the individual is encouraged to take care of this strategic role (Clarke and Patrickson, 2008).

The responsibility of the individual is as follows:

- Be responsible for assessing himself. Therefore, he can define his training needs.

- Prepare plans to improve his career track proportionate with his skills, knowledge and experience.

- Capability to conform to variables that may influence career planning.

- A good recognition of the job depiction makes the individual able to proceed in the career path better suited to the multi-directional career path.

- Define the type of track that follows through the stages of career within the organization.

B - Responsibility of Directors:

- Provide support and help employees to improve their implementation by supplying them with sufficient information about their performance levels as well as the demands of several jobs.

- Discussing with the employees to improve the career track and support them to achieve the expansion plans. This has been performed through the following steps.

-Training and education: Managers ought to acknowledge the abilities of the employees and argue how to evolve them and benefit from their strengths and diminish the weaknesses.

- Evaluation and follow-up: managers assess employees and assure persistent follow up

- Guidance and guidance: listening to proposals and responding to complaints by subordinates (Al-Subaiy 2010)

- Working with employees to correct their functional situations, solve outstanding problems with management and enhance more career track plans. 
- Helping to originate a connection between the workers to help them carry on their career path and get rid of impediments that may block the worker's work. (Tabil 2013)

C. Responsibility of the Organization:

- Providing training tools and materials for the development process, as well as providing appropriate organizational structures for the employees.

- Continuous development of training programs that help to deny career development plans to all employees in the organization.

- Motivating employees to manage their careers.

- The adoption of the organization on different types of career paths that suit the different functions.

- To link career planning to the Succssion Plan with the aim of providing future staffing needs of the organization.

- Urging employees to test the career path best suited to their abilities and desires.

- Follow the policy of rotation within the organization, which leads to the development of skills and helps to retain staff in the long term.

- Determine the on-the-job training of the employees on appointment and clarifies the functions they may occupy during their careers.

D. Obstacles to career planning:

There are many constraints that affect the career planning of employees such as (Jihad \& Coolahan, 1996) and can be presented as follows:

- Ambiguity of the concept of career path and lack of awareness of its importance by senior management in organizations.

- Career planning is not considered among the primary tasks and responsibilities of managers.

- Some managers believe that planning career path may destabilize the organization because it includes promotion and functional movement.

- Lack of information about the career path and its problems and ways of development

- Lack of skill of managers in the management of workshops on the career path of employees to guide them and help them in the development of career paths

- The lack of adequate budgets by most institutions to conduct research and studies on ways to plan and develop the career path

- The ineffectiveness of linking career planning with individual and organizational performance and incentive system

- Technology impacts on career planning and advancement opportunities as an organization that utilizes complex technology hampers technical professions. Otherwise, the organization, utilizing a simple technology, enables the technical profession to move to another track 
- Lack of manpower planning for the lack of a quantitative and qualitative forecast.

- Restructuring the organizational structure of the organization, dispensing workers and increasing the turnover of workers.

To avoid these constraints, the following can be followed (Jenny M. H et al., 2011; McDonald et al., 2005)

- Training, education, experience and practical and scientific preparation

- Develop personal traits such as self-confidence and independence in decisions

- Attention to work, commitment, ambition and motivation for success

- Providing financial resources to invest in human resources in education and development.

6. Factors influencing career planning for employees:

Hong $\mathrm{Ng}$, et at 2017 divided the factors that influence the choice of careers of employees, as follows:

Self-motivation:

It is the interior motivations of the individual and its psychological style, values and realization, which inspire a spirit of challenge within the individual itself. These motives are not influenced by external factors like rewards or work pressures. The consequences displayed that these factors have a positive and strong effect on the decision to select the career path of the individual.

B. External variables:

Based on something external that supports the individual to pay attention to the choice of career path, like reparations, the benefits offered by a particular job, job security, stability in work, as well as economic and social conditions prevailing in the surrounding environment.

C. Effect of the three extremes:

Family, friends, employment offices and their capability to assure the individual to choose his career path. As Agarwala (2008) has observed, parents have a strong effect on children in choosing their career path, where the father is the first to impact and the mother follows.

D. Factors related to the provision of job information:

Providing information about the job empowers the individual to create the prospective mental image of the job, which aids in the procedure of selecting the career track. However, the absence of this information leads to the unwillingness of the individual. The best information that can be provided for the job is presented by the practitioners themselves as they reflect reality practically with this function.

E) Demographic factors affect career choice: 
Such as age, gender, social status and education (Barbara-I et al., 2017). Other factors support the person to select the career path, such as individual skills and abilities, as well as educational background and training (Agarwala, 2008).

\section{Search procedures}

The aim of the present research is to identify the employees' competence in the fast food restaurants and to plan their career path. It describes the procedures of the field research to achieve the research objectives. It includes defining the research methodology, the research community, the research sample, the research tool, verifying its validity and stability, Results.

\section{Research Methodology:}

In order to achieve the objectives of the study, I used the analytical descriptive approach: "The descriptive approach is concerned with the collection, classification and classification of data and facts; in addition to analyzing them in depth and in depth; it also includes some interpretation of these results; And to reach generalizations about the phenomenon under study

\section{Search community and design:}

The research community consisted of McDonald's employees. The random sample was randomly selected from the employees of McDonald's in Saudi Arabia. The sample number was (164) individuals

\section{Search Tool:}

After reviewing the previous studies related to the subject of the research, the researcher built and developed a questionnaire to identify the merit of workers in fast food restaurants to plan their career path.

In order to obtain the necessary information from the sample items to answer the research questions, it relied on the questionnaire as a basic tool for collecting the data required to support theoretical research in the practical aspect of answering its questions and achieving its objectives.

\section{Description of the Search Tool:}

In its final form, the questionnaire contains (4) main axes that serve the purpose of the study

\section{The Validity of the search tool:}

\section{- Virtual Validity:}

After the completion of the questionnaire and the construction of its paragraphs, the questionnaire was presented in its initial form to a group of arbitrators, in order to ascertain the extent to which each of its paragraphs is related to the axis to which it belongs, the clarity of each paragraph and the correctness of its language formulation and its suitability to achieve the objective set for it. Ways to improve them by deleting, adding, reformulating or otherwise stating what they deem appropriate. 
After the restoration of the court copies of the arbitrators, and in the light of the proposals of some arbitrators, the questionnaire was reworded. Some of the statements in the questionnaire were deleted and reworded, as agreed by more than $80 \%$ of the arbitrators. The questionnaire became final after verifying its veracity Consisting of (26) paragraphs.

\section{Validate the internal consistency of the search tool:}

\section{- Verify the internal consistency of the resolution paragraphs}

The validity of the internal consistency was calculated according to the responses of the survey sample which reached (30) individuals by calculating Pearson correlation coefficient between the scores of each paragraph and the total score of the axis to which the paragraph belongs as in table (1).

Table (1) The internal consistency of the paragraphs of the questionnaire

\begin{tabular}{|c|c|c|c|c|c|c|c|}
\hline \multicolumn{2}{|c|}{ First axis } & \multicolumn{2}{|r|}{ Second axis } & \multicolumn{2}{|r|}{ Third axis } & \multicolumn{2}{|r|}{ Fourth axis } \\
\hline No & $\begin{array}{r}\text { Person } \\
\text { correlation } \\
\text { coefficient }\end{array}$ & No & $\begin{array}{r}\text { Person } \\
\text { correlation } \\
\text { coefficient }\end{array}$ & No & $\begin{array}{r}\text { Person } \\
\text { correlation } \\
\text { coefficient }\end{array}$ & No & $\begin{array}{r}\text { Person } \\
\text { correlation } \\
\text { coefficient }\end{array}$ \\
\hline 1 & $.959 * *$ & 1 & $.938 * *$ & 1 & $.539 * *$ & 1 & $.497 * *$ \\
\hline 2 & $.886^{* * *}$ & 2 & $.978 * *$ & 2 & $.557 * *$ & 2 & $.548 * *$ \\
\hline 3 & $.921 * *$ & 3 & $.847 * *$ & 3 & $.592 * *$ & 3 & $.553 * *$ \\
\hline 4 & $.936 * *$ & 4 & $.933 * *$ & 4 & $.566 * *$ & 4 & $.608 * *$ \\
\hline 5 & $.963 * *$ & 5 & $.967 * *$ & 5 & $.535 * *$ & 5 & $.514 * *$ \\
\hline 6 & $.893 * *$ & & & 6 & $.690 * *$ & 6 & $.568 * *$ \\
\hline 7 & $.921 * *$ & & & & & 7 & $.582 * *$ \\
\hline 8 & $.940 * *$ & & & & & & \\
\hline
\end{tabular}

from Table (1) we conclude that the correlation coefficients of the paragraphs of the axis to which the paragraph belongs were all statistically significant at the level of (0.01). All correlation coefficients were high, indicating a high degree of internal consistency For the axes of the questionnaire axis

\section{Calculate the internal consistency between the axes of the questionnaire}

The validity of the internal consistency between the study axes was calculated by calculating Pearson correlation coefficient between the scores of each axis and the total score of the questionnaire as shown in Table (2)

Table (2): The internal consistency between the axes of the questionnaire

\begin{tabular}{|r|r|}
\hline Axis & Coefficient of correlation \\
\hline The first axis & $.792^{* *}$ \\
\hline The second axis & $.802^{* *}$ \\
\hline The third axis & $.653^{* *}$ \\
\hline The fourth axis & $.770^{* *}$ \\
\hline
\end{tabular}


Table (2) shows that the coefficients of the axis correlation were all statistically significant at the level (0.01). All values of the correlation coefficients were high, indicating a high degree of internal consistency.

\section{reality of the search tool:}

In order to calculate the reality of the search tool, the alpha-cronbach reality coefficient was found for the axes of questionnaire. The results are as shown in Table (3)

Table (3) Alpha cronbach coefficient of the study axes

\begin{tabular}{|c|c|c|}
\hline Axis & No. of paragraphs & $\begin{array}{l}\text { alpha-cronbach } \\
\text { coefficient }\end{array}$ \\
\hline The first axis & 8 & 972 \\
\hline The second axis & 5 & .952 \\
\hline The third axis & 6 & .806 \\
\hline The fourth axis & 7 & .719 \\
\hline Total degree & 26 & .935 \\
\hline
\end{tabular}

From the table (3) we find that the reality coefficients of the axes were all of a high degree close to the correct one, and we find that the value of the total degree of the coefficient of Alpha cronbach for the questionnaire as a whole came with a high value equal to (.935) The value to the validity of the questionnaire for the application and the reliability and reliability of its results.

\section{Describe the method of applying the questionnaire to the sample}

The researcher carried out the field research through the following steps and procedures:

- Investigate the research problem of the research community by conducting a survey on a number of McDonald's employees and senior management who work in the field of fast food restaurants in Saudi Arabia.

- Prepare search tools by preparing a 26-item questionnaire.

- Verification of the validity and stability of the study tool on a survey sample (30).

- Obtain a letter to facilitate the task of the researcher from the competent authorities.

- Go to McDonald's in Saudi Arabia and start preparing for the field application.

- After limiting the research community, the researcher applied the questionnaire himself to the sample members who agreed to participate in the research. 
- Start applying research tools through the researcher to conduct interviews of the company's employees.

- Questionnaires were distributed to the research community, identifying correct questionnaires, excluding damaged questionnaires, and the percentage of correct questionnaires was (82\%) of the total (200) questionnaires Consequently, the number of correct questionnaires represented in the study sample was (164)

- Survey data were collected and entered into the statistical analysis program (SPSS)

\section{Statistical Methods:}

Based on the nature of the research and the objectives that the researcher sought to achieve, the data were analyzed using the statistical package for social sciences (SPSS) and the results were extracted according to the following statistical methods:

1- The averages and the standard deviations: to calculate the mean of the questionnaire expressions as well as the total scores of the points of the questionnaire based on the responses of the members of the research sample

2- Alpha Cronbach: to calculate the stability of the terms of the questionnaire.

3- Range equation: To describe the arithmetic mean of responses on each paragraph and as follows:

The degree of response is determined so that the score (3) gives a large response, the score (2) for the medium response, the score (1) for the response is weak, the degree of participation (direction) for each paragraph or axis is determined based on the following:

Weak: 1 - 1.66., Medium: 1.67 - 2.33, large: 2.34 - 3 .

\section{First, answer the study questions and present the results:}

Question 1: "What knowledge and skills are associated with the field of work?"

To identify the knowledge and skills related to the field of work were studied paragraphs of the first axis and determine the mean arithmetic and standard deviation and direction of each paragraph of the axis as well as the general average of all paragraphs of the axis as shown in table (4). 
Table (4) mean, standard deviation and degree of approval of the first axis

\begin{tabular}{|l|l|r|r|r|}
\hline No & Paragraph & Mean & $\begin{array}{r}\text { standard } \\
\text { deviation }\end{array}$ & Degree \\
\hline 1 & $\begin{array}{l}\text { I know exactly the tasks, duties and actions that my } \\
\text { job includes. }\end{array}$ & 2.50 & .712 & 6 \\
\hline 2 & I can accurately determine the steps of my job. & 2.87 & .401 & 1 \\
\hline 3 & $\begin{array}{l}\text { I know very well the organizational procedures for } \\
\text { my job. }\end{array}$ & 2.48 & .520 & 7 \\
\hline 4 & $\begin{array}{l}\text { I can accurately identify the tools (equipment) that } \\
\text { help me to perform my work. }\end{array}$ & 2.60 & .615 & 4 \\
\hline 5 & $\begin{array}{l}\text { I have the ability to deal better with any job updates } \\
\text { (additional tasks, help tasks ... etc). }\end{array}$ & 2.58 & .643 & 5 \\
\hline 6 & $\begin{array}{l}\text { I have the ability to accept any circumstances that } \\
\text { may be encountered in the performance of my work } \\
\text { (hazardous sources, unusual circumstances, etc.). }\end{array}$ & 2.79 & .732 & 2 \\
\hline 7 & I can offer new ideas for better performance. & 2.40 & .901 & 8 \\
\hline 8 & I can plan well to do my job as required. & 2.62 & .534 & 3 \\
\hline
\end{tabular}

From the previous table we concluded that the knowledge and skills associated with the field of work came to a large extent. The general average of the paragraphs of this axis (2.61) and the standard deviation (0.62) and the general trend of paragraphs (large) The standard deviation of all the paragraphs of the axis of low value indicates the homogeneity of the opinions of the members of the research sample on these paragraphs.

This indicates the importance of knowledge and skills related to the field of work. The most important of these were the skills (I can accurately determine the steps of my job.) with mean (2.87 ) then (I have the ability to accept any circumstances that may be encountered in the performance of my work (hazardous sources, unusual circumstances, etc.).) with mean (2.79)

From the above we conclude that the employee must identify the knowledge and skills associated with his field of work in order to be able to perform his job to the fullest and enable him to overcome the obstacles faced(Cappellen and Jenssens, 2008)

Question 2: "What is the effect of the worker's ability to use the necessary resources to perform his work?"

In order to identify the worker's ability to use the resources required to perform his work, the second axis, the mean, the standard deviation, the direction of each paragraph , and the general mean of all paragraphs were studied as table (5) 
Table (5) The mean, the standard deviation and the degree of approval for the second axis.

\begin{tabular}{|c|l|c|c|c|}
\hline No & \multicolumn{1}{|c|}{ Paragraph } & Mean & standard deviation & Degree \\
\hline 1 & $\begin{array}{l}\text { I use the resources available to me to do } \\
\text { my job better. }\end{array}$ & 2.62 & .624 & 4 \\
\hline 2 & $\begin{array}{l}\text { I can specify the necessary information } \\
\text { for my work. }\end{array}$ & 2.58 & .701 & 5 \\
\hline 3 & $\begin{array}{l}\text { I can analyze the information available } \\
\text { to me in a good and good way in order to } \\
\text { achieve better performance in my work. }\end{array}$ & 2.79 & .422 & 1 \\
\hline 4 & $\begin{array}{l}\text { I have the ability to make good use of } \\
\text { available resources to cope with any } \\
\text { changes in the procedures that I face } \\
\text { while working. }\end{array}$ & 2.74 & .541 & 2 \\
\hline 5 & $\begin{array}{l}\text { I can identify the best available resources } \\
\text { in a way that helps me cope with } \\
\text { business problems. }\end{array}$ & 2.68 & .763 & 3 \\
\hline
\end{tabular}

From the previous table, we conclude that the worker must be able to use the resources required to perform his work according to the research community. The general mean of paragraphs (2.68), standard deviation (0.61), and the general trend of paragraphs (large) The standard deviation of all the paragraphs of the axis of low value indicates the homogeneity of the opinions of the members of the research sample on these paragraphs. This indicates that the members of the research sample agreed to a great extent on the ability of the worker to use the resources necessary to perform his work.

In the first order From the point of view of the members of the research sample (I can analyze the information available to me in a good and good way in order to achieve better performance in my work.) With mean (2.79) then (I have the ability to make good use of available resources to cope with any changes in the procedures that I face while working.) with mean (2.74) and (I can identify the best available resources in a way that helps me cope with business problems) with mean (2.68)

From the above we conclude that the ability of the worker to perform his work enables the worker to perform his work easily and thus leads to the efficiency and quality of the product (Skilton 2008)

Question 3:" How is the relationship between colleagues at work? "

To identify the relationship between colleagues at work, The third axis was studied, the mean, the standard deviation, the direction of each axis, and the general mean of all paragraphs, as shown in Table 6 below. 
Table (6) mean, the standard deviation and the degree of approval of the third axis

\begin{tabular}{|c|l|c|c|c|}
\hline No & Paragraph & Mean & $\begin{array}{r}\text { standard } \\
\text { deviation }\end{array}$ & Degree \\
\hline 1 & $\begin{array}{l}\text { There is an understanding between me and } \\
\text { my colleagues at work constantly. }\end{array}$ & 2.78 & .780 & 2 \\
\hline 2 & I accept constructive criticism from others. & 2.64 & .720 & 5 \\
\hline 3 & $\begin{array}{l}\text { I have the ability to continuously cooperate } \\
\text { with my colleagues at work. }\end{array}$ & 2.68 & .578 & 4 \\
\hline 4 & $\begin{array}{l}\text { I can overcome any differences in views } \\
\text { between me and my colleagues. }\end{array}$ & 2.80 & .322 & 1 \\
\hline 5 & $\begin{array}{l}\text { I have the ability to remove the differences } \\
\text { that occur between my colleagues at work. }\end{array}$ & 2.75 & .602 & 3 \\
\hline 6 & $\begin{array}{l}\text { Join and work as a member of a team. } \\
\text { General average }\end{array}$ & 2.53 & .822 & 6 \\
\hline
\end{tabular}

From the previous table we concluded that the need for a relationship between colleagues in the work according to the research community The general mean of paragraphs (2.70) and the standard deviation (0.64) and the general trend of the paragraphs (large) indicated that the members of the research sample agreed on the importance of the relationship between the colleagues in the work.

And in the first order (I can overcome any differences in views between me and my colleagues) with an average of (2.80) then (there is an understanding between me and my colleagues at work consistently) with mean(2.78) and (I have the ability to remove the differences that occur between my colleagues at work.)with mean of (2.75)

From the above we conclude the importance of good relations between coworkers, which gives an incentive to encourage the performance of work (Shumba, A. \& Naong, M. 2012)..

Question 4: "How to plan for jobs you want to occupy in the future?"

In order to answer this question, the subjects of the fourth axis were studied, the mean of the arithmetic mean, the standard deviation, the direction of each axis, and the general average of all axes were determined as shown in Table (7) 
Table (7) mean, standard deviation and the degree of approval for the fourth axis

\begin{tabular}{|c|l|c|c|c|}
\hline No & Paragraph & Mean & $\begin{array}{r}\text { standard } \\
\text { deviation }\end{array}$ & Degree \\
\hline 1 & $\begin{array}{l}\text { Planning for career paths contributes to the } \\
\text { development of my abilities in proportion to } \\
\text { the jobs I want to fill in the future }\end{array}$ & 2.78 & .401 & 1 \\
\hline 2 & $\begin{array}{l}\text { I assess my current abilities in a way that helps } \\
\text { me develop them in the future to achieve my } \\
\text { career goals. }\end{array}$ & 2.60 & .642 & 6 \\
\hline 3 & $\begin{array}{l}\text { I know the promotion opportunities available } \\
\text { in the company for the coming years, making } \\
\text { me more capable of planning my careers. }\end{array}$ & 2.65 & .612 & 5 \\
\hline 4 & $\begin{array}{l}\text { My current and future abilities are the basis } \\
\text { upon which I plan my careers. }\end{array}$ & 2.58 & .682 & 7 \\
\hline 5 & $\begin{array}{l}\text { I am constantly adjusting my career } \\
\text { progression plan whenever required. }\end{array}$ & 2.68 & .522 & 4 \\
\hline 6 & $\begin{array}{l}\text { My career planning makes me able to identify } \\
\text { my future training needs. }\end{array}$ & 2.73 & .422 & 2 \\
\hline 7 & $\begin{array}{l}\text { A performance assessment helps me in my } \\
\text { planning of the jobs I want to fill in the future }\end{array}$ & 2.70 & .500 & 3 \\
\hline General average & 2.67 & 0.54 & \\
\hline
\end{tabular}

From the previous table, we concluded that The importance of developing a plan for the jobs that the employees wish to occupy in the future. The general mean of this axis (2.67) and the standard deviation (0.54) and the general trend of the paragraphs (large) The standard deviation of all the paragraphs of the axis with low value indicates the homogeneity of the opinions of the members of the research sample on these paragraphs. This is achieved through (the planning of career paths in the development of my abilities, including Suitable for jobs I would like to fill in the future.) With mean (2.78), then (My career planning makes me able to identify my future training needs.) with mean (2.73) and (A performance assessment helps me in my planning of the jobs I want to fill in the future.) with mean (2.70)

From the above we conclude the importance of worker planning for jobs in the future, this encourages him to master his work and work maximum effort to reach the best work (Clarke and Patrickson, 2008)

\section{Second verification of the study hypotheses:}

The first hypothesis: There is a statistically significant relationship between the individual's knowledge of work skills and his ability to use the resources necessary for his work 
To verify this hypothesis, the Person Correlation test was used to find the relationship between the variables and the results Table (8): Relationship between the individual's knowledge of work skills and his ability to use the resources required for his work

\begin{tabular}{|l|l|l|}
\hline & & $\begin{array}{l}\text { The worker's ability to use the } \\
\text { resources necessary for his work }\end{array}$ \\
\hline $\begin{array}{l}\text { Knowledge of individual } \\
\text { work skills }\end{array}$ & $\begin{array}{l}\text { Pearson } \\
\text { Correlation }\end{array}$ & $.865^{* *}$ \\
\cline { 2 - 3 } & Sig. (2-tailed) & .000 \\
\cline { 2 - 3 } & $\mathrm{N}$ & 164 \\
\hline
\end{tabular}

The previous table shows that there is a statistically significant relationship between the individual's knowledge of work skills and his ability to use the necessary resources for his work. The level of significance is equal to $(0.00)$ less than (0.05) indicating a statistically significant relationship. The correlation coefficient is equal to (0.865) Indicate a direct relationship between them This means that by increasing the knowledge of the individual skills of work increases the ability of the worker to use the resources necessary for his work and this leads to the emergence of work in the best possible way as in (Sengupta, 2013) The results indicated that the merit approach is considered a key element in the development of performance to achieve competitive advantage

The results also added that there is a strong link between the merit model and performance management as performance management is a strategic function of human resources management that helps the organization to achieve competitive advantage as (Tarawneh 2010) and the results confirmed that human relations have a strong impact on career planning, as it is one of the approaches to development and promotion within the organization.

The second hypothesis: There is a statistically significant relationship between colleagues' relations in work and their ability to use the resources necessary for their work

To verify this hypothesis, the Person Correlation test was used to find the relationship between the variables and the results 
Table (9): The relationship between colleagues' relations in work and their ability to use the resources required for their work

\begin{tabular}{|l|l|l|}
\hline & & $\begin{array}{l}\text { The worker's ability to use the } \\
\text { resources necessary for his work }\end{array}$ \\
\hline $\begin{array}{l}\text { Colleagues in labor } \\
\text { relations }\end{array}$ & $\begin{array}{l}\text { Pearson } \\
\text { Correlation }\end{array}$ & $722^{* *}$ \\
\cline { 2 - 3 } & Sig. (2-tailed) & .000 \\
\cline { 2 - 3 } & $\mathrm{N}$ & 164 \\
\hline
\end{tabular}

The previous table shows that there is a significant statistical relation between the relations of colleagues in work and their ability to use the resources required for their work. The level of significance is equal to (0.00) less than (0.05) indicating a statistically significant relationship. The coefficient of correlation is (0.722) Indicate a direct relationship between them This means that with strong connections between co-workers, their ability to use the resources needed for their work increases and their appetite for work increases . The third hypothesis: There is a statistically significant relationship between the individual's knowledge of work skills and the planning of his functions in the future

To verify this hypothesis, the Person Correlation test was used to find the relationship between the variables and the results

Table (10) Relationship between the individual's knowledge of work skills and the planning of his functions in the future

\begin{tabular}{|l|l|l|}
\hline & & \multicolumn{1}{|c|}{ Planning future worker functions } \\
\hline $\begin{array}{l}\text { Knowledge of individual } \\
\text { work skills }\end{array}$ & Pearson Correlation & $.876^{* *}$ \\
\cline { 2 - 3 } & Sig. (2-tailed) & .000 \\
\cline { 2 - 3 } & $\mathrm{N}$ & 164 \\
\hline
\end{tabular}

The previous table shows that there is a statistically significant relation between the individual knowledge of the work skills and the planning of his functions in the future. The level of significance is equal to $(0.00)$ less than $(0.05)$ indicating a statistically significant relationship. The correlation coefficient is equal to (0.876) Indicate a direct relationship between them This means that An increase in the knowledge of the individual working skills increases his ambition and ability to plan his future jobs as in (Cappellen and Jenssens, 2008) The results indicated that managers were interested in knowledge in order to develop their careers. 
Fourth hypothesis: There is a statistically significant relationship between the worker's ability to use the resources required for his work and planning his future jobs

To verify this hypothesis, the Person Correlation test was used to find the relationship between the variables and the results

Table (11) The relationship between the worker's ability to use the resources required for his work and planning his future jobs

\begin{tabular}{|l|l|l|}
\hline & & Planning future worker functions \\
\hline $\begin{array}{l}\text { The worker's ability to } \\
\text { use the resources } \\
\text { necessary for his work }\end{array}$ & Pearson & $.740^{* *}$ \\
\cline { 2 - 3 } & Correlation & \\
\cline { 2 - 3 } & Sig. (2-tailed) & .000 \\
\hline
\end{tabular}

The previous table shows that there is a statistically significant relation between the worker's ability to use the resources required for his work and the planning of his functions in the future, where the level of significance is equal to $(0.00)$ less than (0.05) indicating a statistically significant relationship. The correlation coefficient is equal to (0.770) Indicate a direct relationship between them This means that the greater the ability of the worker to use the resources necessary for his work, the greater the ability of the worker to plan for his future jobs as in (Pinnington 2011) The results proved that the development of merit strongly affects the development of the career path of employees of this company.

\section{In view of the results reached, the following conclusions can be drawn:}

- The knowledge and skills associated with the field of work came to a large extent. The general average of the paragraphs of this axis (2.61) and the standard deviation (0.62) and the general trend of paragraphs (large)

- The worker must be able to use the resources required to perform his work according to the research community. The general mean of paragraphs (2.68), standard deviation (0.61), and the general trend of paragraphs (large)

- $\quad$ The need for a relationship between colleagues in the work according to the research community The general mean of paragraphs (2.70) and the standard deviation (0.64) and the general trend of the paragraphs (large)

- The importance of developing a plan for the jobs that the employees wish to occupy in the future, where The general mean of this axis (2.67) and the standard deviation (0.54) and the general trend of the paragraphs (large) 
- There is a statistically significant relationship between the individual's knowledge of work skills and his ability to use the resources required for his work

- There is a statistically significant relationship between colleagues' relationships in work and their ability to use the resources required for their work

- There is a statistically significant relationship between the individual's knowledge of work skills and the planning of his / her functions in the future

- There is a statistically significant relationship between the worker's ability to use the resources needed for his work and planning his future jobs

\section{Search recommendations:}

In light of the results of the research, the following recommendations can be made:

- Define the worker with the tasks and actions that must be performed

- Encourage employees to provide new ideas and work to support them

- The resources available for the functioning of the worker should be made available

- Encouraging staff to work in team spirit

- Encourage employees to establish relations between them and work to exchange visits among themselves

- Employ employees for jobs that fit their abilities 


\section{reference}

1. Agarwala Tanuja , (2008) " Factors influencing career choice of management students in India", Career Development Inerntional, Vol. 13 Issue : 4, pp $362-367$.

2. Alice H.Y.Hon (2012). When competency-based pay relates to creative performance: The moderating role of employee psychological need. International Journal of Hospitality Management, vol 31 pp $130-138$.

3. Al-Tarawneh, Ibrahim Ahmed (2010), "The Impact of Human Resource Management Functions on the Career Track of Ministry of Finance Employees in Jordan": Muta Research and Studies - Human and Social Sciences, Jordan, vol.

4. Ashosh, Mohammed Ayman Abdel Latif (2015). Human Resources Management in the Work Place: The Scientific Basis and Applied Practice "Cairo: Publishing Publisher, Publisher, p. 435, p. 439.

5. Awarib, Abdelgadir (2015). The role of career path planning in motivating workers in small and medium enterprises. Master Thesis, Faculty of Economics, Business and Management, University of Kasidi Merbah, Ouargla, Algeria.

6. Badawi, Mamoun Yassin\& Farah, Farah Yassin (2018). The Impact of Information Technology on Development of Human Resources Digital Competence in Saudi Construction and Contracting Companies: A Case Study of ABSAR Limited Company. Journal of Economic and Social Sciences. Vol (9), Issue (1). Pp.1-37.

7. Balochia, Moushira bint Abdullah bin Fakir (2010). Second Arab Conference (Human Resource Development and Strengthening the National Economy) Arab Organization for Administrative Development Sultanate of Oman.

8. Barbara - I Alba - Molinero, Rosalia Cascon - Pereira, Ana beatriz Hernandez - Lara, (2017) "Professional identity development in higher education : influencing factors" , International Journal Of Educational Management, Vol. 31 Issue: 2, pp 189 - 203

9. Baruch Yehuda, (2004) .Transforming careers: from linear to multidirectional career paths: Organizational and individual perspectives. Career Development International, Vol. 9 Issue 1, pp. $58-73$.

10.Bocciardi, Federica\& Caputo, Andrea (2017). Career adaptability as a strategic competence for career development: An exploratory study of its key predictors. European Journal of Training and Development, Vol. 41 Issue: 1, pp.67

11.Bravenboer, Darryll\& Lester, Stan (2016). Towards an integrated approach to the recognition of professional competence and academic learning. Education + Training, Vol. 58 Issue: 4, pp.409-421.

12.Canning, Louise\& Szmigin, Isabelle (2016). Radical innovation, network competence and the business of body disposal. Journal of Business \& Industrial Marketing, Vol. 31 Issue: 6, pp.771-783

13.Cappellen, Tineke\& Janssens Maddy, (2008). Global managers' career competencies. Career Development International, Vol. 13 Issue: 6, pp.514-537.

14.Clarke, Marilyn\& Patrickson, Margaret (2008). The new covenant of employability. Employee Relations, Vol. 30 Issue: 2, pp.121-141

15.Dada, Joshua Oluwasuji\& Musa, Nofiu Abiodun (2016). Key factors affecting the competence of quantity surveyors: Evidence from construction industry stakeholders in Nigeria. Journal of Engineering, Design and Technology, Vol. 14 Issue: 3, pp.461-474

16.Daniel Tzabbar, Yoav Vardi, Yehuda Baruch, (2003) "Organisational career management in Israel", Career Development International, Vol. 8 Issue: 2, pp.88-96, 
17.Dessler , G. (2008). Human Resources Management : New Jeresy Prentice Hall , Upper Saddle River ,pp 321.

18.Eden, Colin\& Ackermann, Fran (2010). Competences, distinctive competences, and core competences, in Ron Sanchez, Aimé Heene, Thomas Ede Zimmermann (ed.) A Focussed Issue on Identifying, Building, and Linking Competences (Research in Competence-Based Management, Volume 5) Emerald Group Publishing Limited, pp.3 - 33

19.Fleisher, Chen\& Svetlana N. Khapova, Paul G.W. Jansen, (2014). Effects of employees' career competencies development on their organizations: Does satisfaction matter?. Career Development International, Vol. 19 Issue: 6, pp.700-717

20.Furåker, Carina\& Nilsson, Agneta (2010). Age care managers in residential facilities aspects of competence. Leadership in Health Services, Vol. 23 Issue: 1, pp.33-45

21.Garavan,Thomas N\& Coolahan, Michael (1996).Career mobility in organizations: implications for career development - Part I. Journal of European Industrial Training, Vol. 20 Issue: 4, pp.30-40.

22.Hong Ng,Yen\& Sue-Pei Lai, Zhi-Peng Su, Jing-Yi Yap, Hui-Qi Teoh, Han Lee (2017). Factors influencing accounting students' career paths. Journal of Management Development, Vol. 36 Issue: 3, pp.319-329

23.James J. Kirk, Bridget Downey, Steve Duckett, Connie Woody, (2000) "Name your career development intervention", Journal of Workplace Learning, Vol. 12 Issue: 5, pp.205-217.

24.Jenny M.H. Sok, , Rob J. Blomme, , Debbie M. Tromp, , Jaap J. Van Muijen, (2011). Exploring Success Factors in Top Careers in the Netherlands, in Joseph S. Chen (ed.) Advances in Hospitality and Leisure (Advances in Hospitality and Leisure, Volume 7) Emerald Group Publishing Limited, pp.3- 27

25. Jihad, Dina Fadel (2011). The impact of individual narratives on the performance of workers in five star hotels in Jordan applied study. Master Thesis, Amman Arab University. P.

26.Junaidah, Hashim\& Saodah, Wok (2013). Competence, performance and trainability of older workers of higher educational institutions in Malaysia. Employee Relations, Vol. 36 Issue: 1, pp.82-106

27.Jung, Yuhee\& Takeuchi, Norihiko (2016). Gender differences in career planning and success. Journal of Managerial Psychology, Vol. 31 Issue: 2, pp. 603-623.

28.Krishnan, T.N.\& Maheshwari, Sunil Kumar (2011). A re-conceptualization of career systems, its dimensions and proposed measures. Career Development International, Vol. 16 Issue: 7

29. Mamaqi, Xhevrie \& Jesus Miguel, Pilar Olave, (2011). Evaluation of the importance of professional competences: the case of Spanish trainers. On the Horizon, Vol. 19 Issue: 3, pp.174-187.

30.McDonald, Paula\& Kerry Brown, Lisa Bradley, (2005). Have traditional career paths given way to protean ones?: Evidence from senior managers in the Australian public sector. Career Development International, Vol. 10 Issue: 2, pp.109-129,

31.Medina, Rolf\& Medina, Alicia (2015) "The competence loop: Competence management in knowledge-intensive, project-intensive organizations", International Journal of Managing Projects in Business, Vol. 8 Issue: 2, pp.279-299

32.Meyer, Gerrit\& Nyhuis, Bianca Brünig, Peter (2015). Employee competences in manufacturing companies - an expert survey. Journal of Management Development, Vol. 34 Issue: 8, pp.1004-1018.

33. Mohammed I. Eraqi, Ayman M. Kasem, Suzan B. Hassan, Ahmad M. Ragab, (2011). Towards a comprehensive human resources module for tourism satellite accounts in Egypt. , Tourism Review, Vol. 66 Issue: 4 , pp.30-440. 
34.Mondy, R. Wayne (2010). Human resource management. Upper Saddle River, N.J: Pearson Prentice Hall.

35.Mondy, R.\& Others, (2005) "Human Resource Management " Prentice Hall Upper Saddle River : New Jersey, 9th Edition, pp 367.

36. Mr. Amal Abdel Rahman (2012). Evaluation of the Human Resources Consciousness in Egyptian Organizations for the Culture of Self Development as an Approach to Achieving Competence in Performance "Applied Study, Cairo University Journal of Business Administration, No. 2.

37.Pinnington, Ashly H. (2011). Competence development and career advancement in professional service firms. Personnel Review, Vol. 40 Issue: 4, pp.443-465

38. Rowold, Jens\& Kauffeld, Simone (2008). Effects of career-related continuous learning on competencies. Personnel Review, Vol. 38 Issue: 1, pp.90-101.

39.Sengupta, Atri\& D.N. Venkatesh, Arun K. Sinha, (2013). Developing performance-linked competency model: a tool for competitive advantage. International Journal of Organizational Analysis, Vol. 21 Issue: 4, pp.504-527

40.Shumba, A. \& Naong, M. (2012). Factors influencing students' career and aspirations in South Africa. Journal of Social Sciences, 33(2):169-178.

41.Skilton, Paul F.(2008). Do social capital and project type vary across career paths in project-based work?: The case of Hollywood personal assistants.Career Development International, Vol. 13 Issue:5, pp.381-401

42. Smith-Ruig, Theresa (2008).Making sense of careers through the lens of a path metaphor. Career Development International, vol.13 issue: 1, pp. 20-32.

43. Tabil, Mohammed Ahmed Abdullah (2013) "Planning the career path and its relation to organizational effectiveness in the Ministries of Labor and Social Affairs" unpublished MA thesis - Gaza.

44.Urtasun, Ainhoa \& Núñez, Imanol, (2012). Work-based competences and careers prospects: a study of Spanish employees. Personnel Review, Vol. 41 Issue: 4, pp.428-449.

45.Yu-Chi Wu, Chin-Shih Tsai, Hsiao-Wen Hsiung, Kuan-Ying Chen, (2015).Linkage between frontline employee service competence scale and customer perceptions of service quality", Journal of Services Marketing, Vol. 29 Issue: 3, pp.224-234 